Vol. 2, No. 2, 2019

N. E. Stadnytska, O. R. Bryda, A. A. Hajevska, V. H. Chervetsova, V. I. Lubenets, V. P. Novikov

Lviv Polytechnic National University,

Department of Technology of Biologically Active Substances, Pharmacy and Biotechnology

chervetsova@gmail.com

\title{
INFLUENCE OF GARLIC EXTRACT ON TEST-CULTERES OF FUNGUSES
}

https://doi.org/10.23939/ctas2019.02.129

The development of pharmaceuticals led to an increase in the number of various antifungal agents in the pharmaceutical market. Over the time microorganisms develop resistance to drugs. Therefore, the direction of research on antifungal agents is considered promising. A special place is occupied by medicines based on herbal raw materials, such as garlic (Allium sativum). Therefore, we conducted a study on the effect of Alcoholic extract of garlic on the test culture of fungi Penicillum chryzogenum, Candida lypolitica, Aspergillus niger. As a result, a positive fungicidal effect on culture research can be noted, due to the presence of a complex of biologically active compounds with antimicrobial properties and their successful extraction under the conditions of the experiment.

Key words: garlic, Allium sativum, antimicrobial activity, medicinal plant material, Penicillum chryzogenum, Candida lypolitica, Aspergillus niger

\section{Introduction}

Garlic normal (Allium sativum) is a wellknown spice-aromatic plant with thousands of years experience of using. It is one of the first cultivated plants in the world, which has found its application both in the food industry and in medicine. We know about 500 different representatives of this culture, which are distinguished by color, taste, structure, but similar in their biochemical and phytochemical properties [1].

Studies on garlic revealed strong antimicrobial and antioxidant properties of its extracts [1]. Extracts of garlic different vegetative parts have been shown different strength activities. Often in popular medicine, the use of bulbs of this plant is described [2]. These properties provide a complex of biologically active substances (BAS), among which the most important are the allicin and aioen [1].

Allicin is a substance with well-known fungicidal and bactericidal properties. This compound is formed as a result of the destruction of garlic bulb cells due to mechanical damage of the cell walls and the subsequent interaction of the alliinase enzyme with alliin. Allicin is unstable at room temperature and in a number of polar and non- polar solvents, so when the exstracting of this compound is done, it is necessary to hold it in the low temperature regimes [3].

During literature data's, the results of the study of the influence of fresh garlic on its water and oil extracts, formation monodisperse microspheres of garlic oil in water, AGE, allicin and aioen were studied $[3,4,5]$. Because of the greater importance, most of them reached the antimicrobial activity of water and water-alcohol extracts of the garlic normal with the maximum amount of alcohol ethyl extractant $-70 \%$. However, all these extracts were characterized by low stability during storage. In this regard, we have selected $96 \%$ ethyl alcohol as the extractant to minimize the free water content in the extract, which may possibly help stabilize the finally preparation.

\section{The aim of the research}

The purpose of our study was to obtain a complex of BAS soluble in $96 \%$ ethyl alcohol at low temperature with the further study of their antimicrobial activity on test cultures of different types of microorganisms: Penicillum chryzogenum, Candida lypolitica, Aspergillus niger. 
N. E. Stadnytska, O. R. Bryda, A. A. Hajevska, V. H. Chervetsova, V. I. Lubenets, V. P. Novikov

\section{Materials and methods of research}

To obtain a rich alcoholic extract, the usual garlic bulbs, grown in hothouse conditions, and collected a month before the experiment were used as raw material.

The extract was made in a ratio of 2:3 to extragent $-96 \%$ ethyl alcohol. The grinding of raw materials was carried out in cooled containers at a temperature not exceeding $5{ }^{\circ} \mathrm{C}$. After that, the raw materials were left for 1 hour at the refrigeration unit at $4{ }^{\circ} \mathrm{C}$ for the further passage of the enzymatic process in order to isolate allicin.

Table 1

Analysis of antimicrobial activity of BAS complexes and individual substances from Allium sativum

\begin{tabular}{|c|c|c|c|}
\hline $\begin{array}{l}\text { Investigated } \\
\text { component } \\
\text { (material) }\end{array}$ & Test culture & Mechanism of action & Sustainable \\
\hline $\begin{array}{l}\text { Garlic normal } \\
\text { Allium sativum, } \\
\text { exstract }\end{array}$ & $\begin{array}{l}\text { Escherichia coli; Streptococcus mutans; } \\
\text { Patogens of paradontos; } \\
\text { Proteus; Pseudomonas; Klebsiella; } \\
\text { Helicobacter pylori; Shigella dysenteriae; } \\
\text { S. flexneri; S. sonnei; Staphylococcus } \\
\text { aureus; Salmonella enteritidis; } \\
\text { Histoplasma capsulatum; Penicillium } \\
\text { funiculosum; Trichoderma } \\
\text { brevicompactum,Candida albicans; } \\
\text { Mycobacterium tuberculosis; M. avium; } \\
\text { H. capsulatum; Aspergillus parasiticus; } \\
\text { Cryptococcus neoformans Escherichia; } \\
\text { Salmonella; Staphylococcus; } \\
\text { Streptococcus; Klebsiella; Proteus; } \\
\text { Bacillus; Clostridium; Mycobacterium } \\
\text { tuberculosis }\end{array}$ & $\begin{array}{l}\text { Destruction of thiol groups in bacterial } \\
\text { enzymes; inhibition of thiol-containing } \\
\text { and other enzyme systems, synthesis } \\
\text { of DNA, RNA and proteins }\end{array}$ & \\
\hline $\begin{array}{l}\text { Garlic oil, mono- } \\
\text { dispersed } \\
\text { microspheres of } \\
\text { garlic oil in water }\end{array}$ & $\begin{array}{l}\text { Helicobacter pylori; enterobacteria; } S \text {. } \\
\text { aureus. }\end{array}$ & & \\
\hline AGE & Candida albicans & $\begin{array}{l}\text { Changing the structure and integrity of } \\
\text { the outer surface of yeast cells, as well } \\
\text { as reducing the total lipid content }\end{array}$ & \\
\hline Allicin & $\begin{array}{l}\text { Aspergillus niger; Cryptococcus; } \\
\text { Staphylococcus; Streptoproteus; E.coli; } \\
\text { Enterococcus } \\
\text { Babesia; Theileria equi; H. capsulatum } \\
\text { E. coli, Enterococcus; Shigella dysenteriae; } \\
\text { S. nerexneri; S. sonnei; S. ner exneri; } \\
\text { Aspergillus parasiticus }\end{array}$ & $\begin{array}{l}\text { Inhibitors of cell wall synthesis, cell } \\
\text { membrane inhibitors, cofibiosynthesis } \\
\text { inhibitors (i.e., production of purines, } \\
\text { pyrimidines, AA, vitamins, proteins, } \\
\text { DNA, RNA), inhibitors of energy } \\
\text { production (inhibit breathing or } \\
\text { dissociation of oxidative } \\
\text { phosphorylation) }\end{array}$ & $\begin{array}{l}\text { Gemolytics } \\
\text { and Entero- } \\
\text { coccus } \\
\text { faecium }\end{array}$ \\
\hline Aioen & $\begin{array}{l}\text { Aspergillus niger; Cryptococcus; } \\
\text { Staphylococcus; E.coli; } \\
\text { grampositive and gramnegative bacteria; } \\
\text { yeasts }\end{array}$ & & \\
\hline
\end{tabular}

For the experiment, chopped raw garlic was harvested in an amount of $65 \mathrm{~g}$. In accordance with the proportion, $121 \mathrm{ml}$ $(97.5 \mathrm{~g})$ of $96 \%$ ethanol was used [13]. Before adding the extract to the raw material, it was left to oxidize the fermenting substances in the open air at a temperature not higher than $10{ }^{\circ} \mathrm{C}$. 


\section{Influence of garlic extract on test-culteres of funguses}

The extraction was carried out for 210 min with periodic sampling for the dry residue test (Fig. 1). Upon completion, the extract was filtered through the gauze, with a final output of $118 \mathrm{ml}$ finished extract (filtrate). The resulting extract was light yellow color with a slight turbidity, viscous, with a characteristic odor. For investigation of stability in one of the samples the quartzetin $(0.01 \%)$ was added.

From the extracts obtained, the amount of extracted substances was determined by the method of determining the dry residue. For this purpose, $2 \mathrm{ml}$ of extract was added to a glass beaker and the extract was evaporated at a temperature of $30{ }^{\circ} \mathrm{C}$. The repetition of experiments was threefold. The amount of extracted substances (ES) was $0.44 \pm 0.05 \mathrm{~g}$.

To determine the fungicidal activity of plant extracts, test cultures of mold fungi Aspergillus niger, Penicillum chryzogenum and yeast Candida lypolitica were used. A suspension of microorganisms in the amount of $10^{6}-10^{7} \mathrm{CFU} / \mathrm{ml}$ was performed in a sterile physiological solution in accordance with the standard of turbidity No. 10.

$1 \mathrm{ml}$ of the suspension was added to Petri dishes and added $30-40 \mathrm{ml}$ of cooled to $40{ }^{\circ} \mathrm{C}$ wort agar $\left(6^{0} \mathrm{~B}\right.$ uncooked beer wort, $2 \%$ agar-agar). After hardening of the medium, sterile glass cylinders $(10 \times 6 \mathrm{~mm})$ were placed on the surface of the agar, immersing them $1 \mathrm{~mm}$ in the medium. Into the cylinders, to the standard procedure [4], $100 \mu$ lof the extracts studied were added. As a control, $96 \%$ ethyl alcohol was used. Petri dishes were placed in a fridge at a temperature of $4{ }^{\circ} \mathrm{C}$ for 30 minutes for dif-fusion of investigated extracts into agar. After that, thedishes were transferred to a thermostat, where microorganisms were cultured at a temperature of $29-30{ }^{\circ} \mathrm{C}$ for $4-5$ days. At the end of cultivation, growth ingibition zones were measured.

\section{Research results and their discussion}

The modern pharmaceutical market offers a large range of synthetic drugs with antimicrobial activity, but their using in many cases leads to the resistance of microorganisms, with accompanied by incident effects on the human body, in particular, the emergence of allergic reactions. These negative aspects may be avoided using herbal drugs. Natural biologically active substances that have antimicrobial activity include plant antibiotics, phytoncides, essential oils, balsams, resins, tannins, organic acids, alkaloids, glycosides.

To determine the optimal extraction time, samples were performed at an extraction every $15 \mathrm{~min}$ to $210 \mathrm{~min}$.

From the data shown in Fig. 1, it was observed that the amount of extraction substances (ES) will rise with the extraction time of medical plant material (MPM). The maximum amount of extraction substances was shown at $150 \mathrm{~min}$. After 150 minutes was observed a little decline in the yield of active substances. It can be concluded that the optimal extraction time is 150 minutes.

Antimicrobial activity of the obtained garlic extract was carried out on cultures of fungus Aspergillus niger, Penicillum chryzogenum and yeast Candida lypolitica, as described in the State Pharmacopoeia of Ukraine. As control $(\mathrm{K})$ was used the ethanol $96 \%$, since it was used as an extragent in basic experiments. The first sample (1) was an extract of garlic without additional substances and the second sample (2) - a garlic extract with the addition of quartzitine $(0.01 \%)$.

As shown in Figure 2, the most effective fungicidal activity of the extracts was demonstrated on Candida lypolitica culture - the average inhibition growth zones for different samples were $30 \pm 2$ and $35 \pm 2 \mathrm{~mm}$ respectively. This result indicates the successful method of extraction due to optimal laboratory conditions and a rather high biological activity of the obtained garlic extract.

In the culture of Penicillum chryzogenum, a positive result for growth ingibition $-32 \pm 1-27 \pm 1 \mathrm{~mm}$ was obtained.

The effect on Aspergillus niger culture of pure garlic extract can be considered moderate, since the growth retardation zone was $16 \pm 1 \mathrm{~mm}$. Quartzetine garlic extract showed higher antifungal activity $-26 \pm 1 \mathrm{~mm}$ growth retardation zone. 
N. E. Stadnytska, O. R. Bryda, A. A. Hajevska, V. H. Chervetsova, V. I. Lubenets, V. P. Novikov

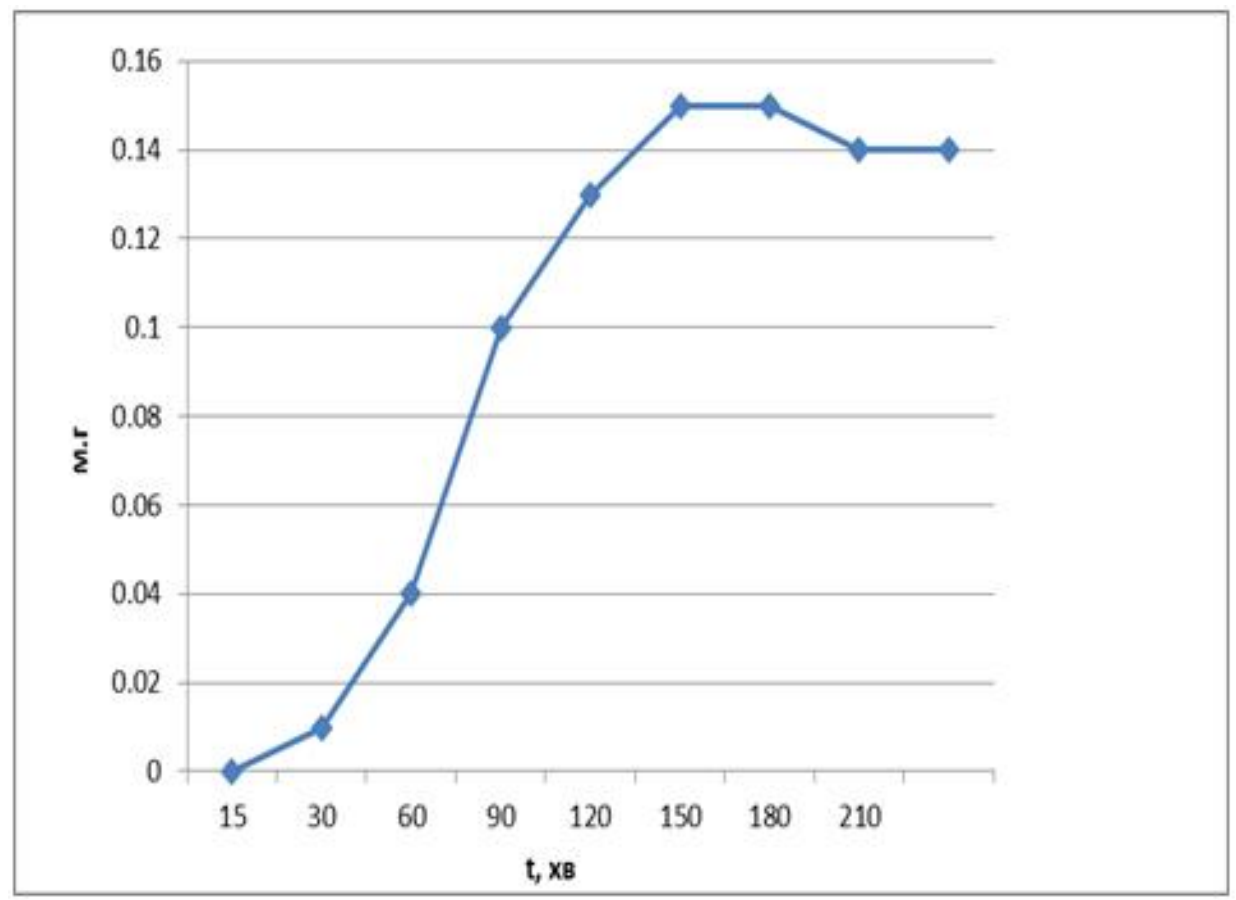

Fig. 1. Dependence of the quantitative content of extractive substances on the duration of extraction

As was shown (Fig. 2), ethanol did not effect on the growth of cultures, so we can concluded that the antimicrobial activity of the extracts studied is

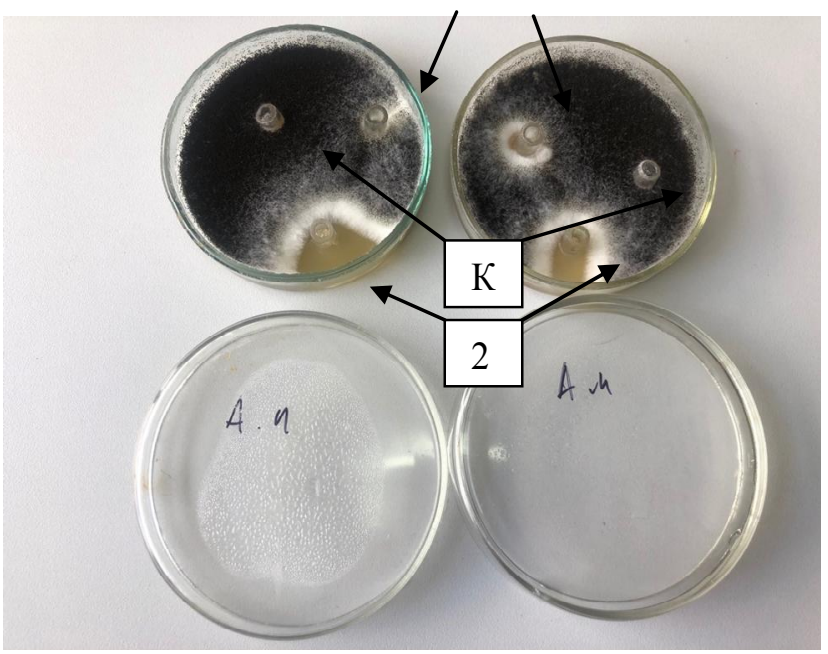

A due to the presence of biologically active substances from garlic in them, not by the using of a powerful antimicrobial extractagent - ethanol.

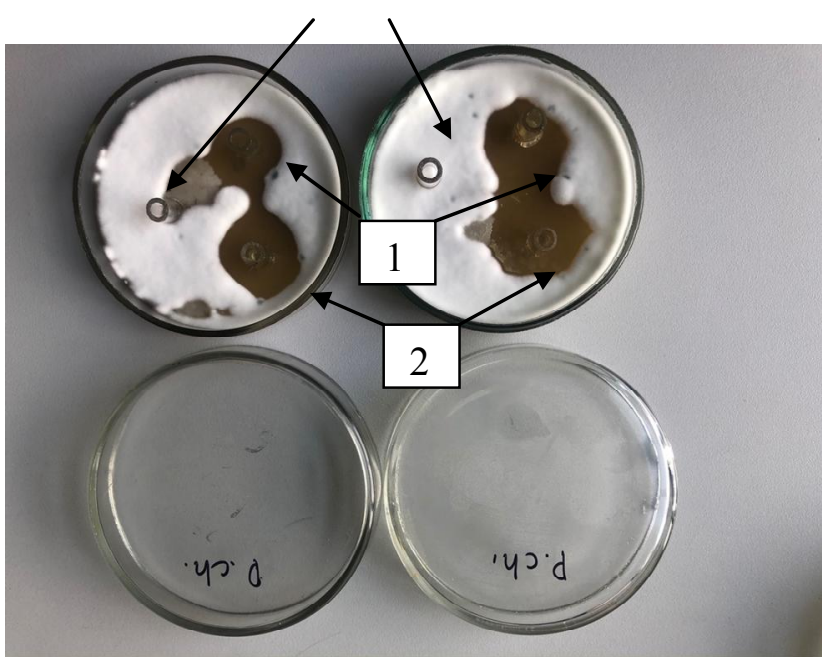

$B$

Fig. 2. Petri dishes with Aspergillus niger (A) cultures; Petri dishes with cultures Penicillum chryzogenum (B). Place on Petri dish: 1) Garlic extract; 2) Quartzetine + garlic extract; K) The control sample with $96 \%$ ethyl alcohol

Determination of the stability of the extracts was carried out by the method of "enhanced aging". This method is elaborated and described in literary sources for chemical pharmaceutical preparations [3], but, unfortunately, there is practically no data on its using in phytotherapy. Due to the fact that the investigational drugs are not resistant at moderate and high temperatures, we placed aliquots of extracts in the thermostat at a temperature of $30^{\circ} \mathrm{C}$ for 30 days. After exposure, the samples have been studied on fungicidal activity according to the procedure described above. As a result, after a month of preparations preserving in a thermostat, the typical odor of 
garlic extracts was observed, but they did not demonstrate fungicidal activity. We suppose that study of the stability of preparations from Allium sativum extracts requires further research.

Table 2

Growth zones of fungus test cultures

\begin{tabular}{|l|l|c|c|c|}
\hline \multirow{2}{*}{ No. } & \multicolumn{2}{|c|}{ Culture } & \multicolumn{2}{|c|}{ Inhibition zone of growth, mm } \\
\cline { 3 - 5 } & & 1 & 2 & $\mathrm{~K}$ \\
\hline 1 & Aspergillus niger & $16 \pm 1$ & $26 \pm 1$ & 0 \\
\hline 2 & Penicillum chryzogenum & $32 \pm 1$ & $27 \pm 1$ & 0 \\
\hline 3 & Candida lypolitica & $35 \pm 2$ & $30 \pm 2$ & 0 \\
\hline
\end{tabular}

\section{Conclusions}

The present study demonstrated that the extract from studied Allium sativum are active against Aspergillus niger, Penicillum chryzogenum and Candida lypolitica and possess a fungicidal activity again this cultures of fungi. We consider that new drugs on the base of garlic extract are perspective for widening the arsenal of antimicrobial herbal preparations.

\section{References}

1. Ravi Kant Upadhyay(2016) Garlic. A potential source of pharmaceuticals and pesticides. A review. International Journal of Green Pharmacy, Jan-Mar (Suppl), 10 (1). S. 1-28.

2. Likars'ki roslyny /za red. A. M. Hrodzins'koho. K.: Vyd-vo "Ukrayins'ka radyans'ka entsyklopediya", 1992. S. 458.

3. S. Ankri, D. Mirelman.(1999) Antimicrobial properties of allicin from garlic. Microbes and Infection, № 1(2). P. 125129.

4. Derzhavna Farmakorpeya Ukrayiny // Derzhavne pidpryyemstvo "Naukoovo-ekspertnyy farmakopeynyy tsentr". 1-e vyd. Kharkiv: IREH, 2001. 556 s. p. 2.7. Biolohichni metody kil'kisnoho vyznachennya 2.7.2. Kil'kisne vyznachennya antybiotykiv mikrobiolohichnym

5. Borlinghaus, J (2014) Allicin: Chemistry and Biological Properties. MDPI and ACS Style.; Molecules, (19), P. 12591-12618.

6. Derzhavna Farmakorpeya Ukrayiny // Derzhavne pidpryyemstvo "Naukoovo-ekspertnyy farmakopeynyy tsentr". 1-e vyd. Kharkiv: RIREH, 2001. 556 s. p. 2.8. Metody farmakohnoziyi 2.8.16. Vyznachennya sukhoho zalyshku ekstraktu.

7. R. R Culter (2002) Antibacterial activity of a new, stable aqueous extract of allicin against methicillinresistant Staphylococcus aureus. British journal of biomedical science. No. 61 (2). P. 1-3.

8. Zelepugin D. Y. (2010) Ispolzovanie sverhcriticheskoi fluidnoi extractii dlya razrabotki novih potentialnyh biocidov na osnove chesnoka (Alium sativum). Sverhcriticheskie fluidy: theoriya $\mathrm{i}$ praktika.

9. Hlybov N. A. Extrakcia phitoncidov chesnoka dly uvelechenia microbiologicheskou stabilnosti mysoprodtktov pri holodilnom hranenii. (2014) Procesy $i$ aparaty harchovyh prodyktov.

10. Pozharnickaya O. N. Vliyania parametrov extragirovania na soderganie serovmesnyh soedeneniy $\mathrm{v}$ maslyanim extracte iz Allium sativum I osobenosti ih opredelenia. (2001) Rastitelnye resursy. 2001.37 (1), S. 103-109.

11. Ejaz S. Extract of garlic (Allium sativum) in cancer chemoprevention. (2003) Experimental Oncology. 25 P. 93-97.

12. Astashkin E. I. Systema vivedeniya CA2+ iz citoplazmy cherez plazmaticheskuy membranu limfocitov cheloveka I vliyaniya na ee activnost allicina. (2003) Zhyrnal membranoy I kletochnoy biologii. 20(4). P. 341348.

13. Haldun A. O. Bacterecidnye svoistva extracta cheremhi I chesnoka posevnogo (2004) Vestnic veterenarii. P. 31-35.

14. Zelepugin D. Y. (2014) Ustoichevost tiosulfatov sverhcriticheskih extractov casnoka (Allium sativum) v polyrnih I nepolyarnih rastvoritelyzh. Sverhcriticheskie fluidy: theoriya I praktika. 9 (2). S. 11-26. 
N. E. Stadnytska, O. R. Bryda, A. A. Hajevska, V. H. Chervetsova, V. I. Lubenets, V. P. Novikov

Н. Є. Стадницька, О. Р. Брида, А. А. Гаєвська, В. Г. Червецова, В. І. Лубенець, В. П. Новіков Національний університет "Львівська політехніка", кафедра технології біологічно активних сполук, фармації та біотехнології

\section{ВПЛИВ ЕКСТРАКТУ ЧАСНИКУ НА ТЕСТ-КУЛЬТУРИ ГРИБІВ}

Розвиток фармацевтики привів до збільшення різноманітних протигрибкових засобів на фармацевтичному ринку. 3 часом у мікроорганізмів розвивасться резистентність до препаратів. Тому напрям досліджень протигрибкових засобів вважають перспективним. Особливе місце займають препарати на основі лікарської рослинної сировини, такої, як часник звичайний (Allium sativum). Тому нами досліджено вплив спиртового екстракту часнику звичайного на тест-культури грибів Penicillum chryzogenum, Candida lypolitica, Aspergillus niger. Можна зазначити позитивний фунгіцидний вплив на досліджувані культури, що зумовлений наявністю комплексу біологічно активних сполук 3 антимікробними властивостями та їх екстракцісю в умовах проведення експерименту.

Ключові слова: часник звичайний, Allium sativum, протимікробна активність, лікарська рослинна сировина, Penicillum chryzogenum, Candida lypolitica, Aspergillus niger 